the sense, say, of the definition used by Prof. P. B. Medawar in a recent article (Encounter, August 1965). To sum up, the book is thorough, reliable, and with a wide range of proven circuit arrangements described in adequate detail ; sufficient, in fact, to enable the engineer to develop the skill necessary for the design of new configurations.

\section{W. Fishwick}

The coverage is so wide that workers in a great number of disciplines will find these two volumes very useful indeed. However, in order to enjoy them to the full, the reader should have a competent knowledge of French, all chapters being in that language. Moreover, if he wishes to have the two volumes on his own shelves, he needs ib respectable bank balance, the price of the two volumes being $£ 305 s, 8 d$.

ELFANOR Zatmis

\title{
ALKALINE EARTH METALS
}

\section{Handbuch der Experimentellen Pharmakologie}

Begrundet von A. Heffter. Fortgefuhrt von W. Heubner. Erganzungswerk. Herausgegeben von O. Eichler und A. Farah. Band 17: Ions Alcalino-Terreux. Teil 1: Systèmes Isolés. Sous-Editeur: Zénon-Marcel Bacq. Pp. xx+574. 148 D.M. Teil 2: Organismes Entiers. Pp. xviii + 1068. 198 D.M. (Borlin: Springer-Verlag, 1963, 1964.)

I these two volumes the editors have brought together twenty Belgian authors who have, between them, contributed seventeen chapters. The first volume deals with the action of the alkaline earth metals studied in isolated preparations, the second with work on whole organisms.

Z.-M. Bacq opons the first volume with an interesting account of the importance of the alkaline earth motals in living matter. In the second chapter, the chemistry and physical chemistry of magnesium, calcium, strontium and barium are discussed by E. Fredericq. The next four chapters deal with the action of the alkaline earths on simple enzymes (L. Massart and R. Vercauteren), blood coagulation (Y. Bounameaux and J. Lecomte), complex enzyme systems (C. Liébecq) and micro-organisms (Z.-M. Bacq). The intra- and extra-cellular distributions of $\mathrm{Ca}$ and Mg are discussed by E. Schoffeniels. This is followed by chapters dealing with the action of alkaline earth motals on tissues of invertebratos (Z. M. Bacq), on nerve fibres and nerve cells (J. A. Cerf and I. Leusen), on neuromuscu lar transmission (J. E. Desmedt), on skeletal (X. Aubort), cardiac (J. G. Henrotte) and smooth muscle (Z.-M. Bacq and R. Charlier) and blood elements (J. Lecomte and Y. Bounameaux). The first volume ends with a most useful review by E. Schoffeniels and Z.-M. Bacq on the factors which control the states of equilibrium of the various cations.

The second volume concentrates on the many metabolic processes in which the alkaline earth metals are involved in the whole organism. The first two chapters are written by M. J. Dallemagne and deal in great detail with calcium in the circulation, bones and teeth. The third chapter is devoted to the cerebrospinal fluid and the central norvous system (I. Lousen) and to the aqueous humour (Z.-M. Bacq). Subsequent chapters deal with problems concerning the kidney (G. Barac), milk (G. Peetors and R. Vercauteren), sweat (Z.-M. Bacq), gastrointostinal socretions (H. Brabant and J. van Geertruyden), blood vessels and allergy (J. Lecomte). The metabolism of magnesium (M. J. Dallemagne) and that of strontium and radiostrontium ( $\mathrm{J}$. Goffart) follow, and the second volume onds with a chapter by J. Lecomte on the toxicity of alkaline earth metals.

This outline of the contents of the two volumes gives some indication of the scope of the work. Prof. Z.-M. Baeq has dono his work of planning and co-ordination admirably and is to be congratulated on having persuaded so many distinguished Belgian workors to join him in this enterprise. All the chapters aro of high quality and presont in a clear manner a wealth of information on a field of wide interost. There are extensive lists of references at the ends of the chapters which add greatly to the usefulness of the book. Moroover, each of the two volumes is self-contained, with its own author and subject index. The drawings are excellent and the volumes beautifully produced.

\section{RESEARCH IN PHOTOGRAPHY}

Mitteilungen aus den Forschungslaboratorien der Agfa-Gevaert AG Leverkusen-München

Band IV. Pp. viii + 474. (Berlin, Heidelborg and New York: Springer-Verlag, 1964.) D.M. 96.

$\mathrm{V}$ OLUME 4 of Mitteilungen aus den Forschungslaboratorien der Agfa-Gevaert $A G$, like its predecessors, comprises a selection of papers originating from the Agfa Laboratories in Leverkusen and Munich. It represents a cross-section of the work in recent years of the Agfa research workers in the field of photographic and related science and technology.

A total of 35 individual papers, 13 of which have previously been published in other journals, cover the following ground: thermo-dynamic studies of the basic photographic process and a review of tho present theories of spectral sensitization; investigations of the growth and crystal habit of silver halide microcrystals and of the composition and stability of the latent image. Other papers give predominantly theoretical treatment of the mechanism of various reactions which are relevant to the photographic process and of development. Anosher section deals with the properties of the processed photographic image and includes papors on the sensitometry as well as on statistical investigations of tolorances of reversal colour films. This part also includes no less than six papers in a field of growing importance which describe investigations into the performance characteristics of photographic layers in terms of the modulation transfer theory.

Papers in the field of organic chemistry range widely: the reaction of coupling compounds with $p$-phenylene-diamines, resulting in the formation of colourless products and of dyes; optical sensitizing dyes; new developer substances; reactive dyos for gelatine and analytical chemistry. Two further contributions are concerned with the preparation and properties of magnetic tape. Finally, there are contributions in the camera and equipment field; on the spectral sensitivity distribution of photo-electronic receivers and on the efficiency of illumination systems. The standard of the experimental work and of its presentation is high throughout. Among the many oxperimental techniques used, electron-microscopic photography deserves special acknowledgment.

The volume has been edited by E. Klein and R. Matejec. Prof. Klein, who is the research director of the Agfa part of Agfa-Gevaert, is co-author of several of the papers. Other contributors include such well-known names as R. Matejec, E. Moisar, J. Eggers, W. Behrendt, G. Langner and W. Püschel.

This volume is dedicated to F. Gajewski, who initiated Agfa research in the photographic field in tho 1930's. It is in this context that ono may understand the reasons for publishing volumes of this kind which cover such a wide range of subject-matter; that is, to demonstrate within and outside the company the valuo of research work which does not always become apparent in the company's products. By the nature of their work, most sciontists in the field would be interested only in some section or sections of this volume, and the majority would be equally well served if the individual papers could appear in the appropriate journals, as many of them have done already. K. O. GaNeUT. 